\title{
The self-centered philanthropist: family involvement and corporate social responsibility in private enterprises
}

\author{
Bin Zhu* (D)
}

\author{
${ }^{*}$ Correspondence: \\ zhubin2015@ruc.edu.cn \\ Department of Sociology, \\ Renmin University of China, \\ Beijing, China \\ The guidance of Professor \\ Li Lulu and the valuable \\ comments offered by \\ anonymous reviewers are \\ appreciated. The author takes \\ sole responsibility for this \\ paper
}

\begin{abstract}
Although corporate social responsibility (CSR) has attracted increasing attention in recent years, systematic studies on the CSR of Chinese enterprises are absent from academic publications. This study examines the effects of family involvement in the CSR of private enterprises. Using private enterprise data in China, the article reveals that, on the one hand, family involvement will improve CSR investment toward community stakeholders; on the other hand, family involvement has a negative effect on the CSR of contractual stakeholders. With the influence of "chaxu geju," the author argues that Chinese families tend to shift between different logics of behavior when faced with people with whom they have different types of relationships and incorporate this behavioral mode into company practices when they engage themselves in management and business affairs.
\end{abstract}

Keywords: Private enterprises, Family involvement, Stakeholder, Corporate social responsibility (CSR)

\section{Introduction}

In recent years, corporate social responsibility (CSR) has drawn increasing social concern and academic interest in China due to the frequent occurrence of public events, such as the environmental movement, food safety incidents, and labor protests. Above all, CSR reflects people's views on the relationship between enterprises and society. People who believe in shareholder supremacy regard enterprises as profit-making organizations pursuing profit maximization. There is no other social responsibility for corporations than to maximize shareholders' interests (Berle 1931; Friedman 1970). In contrast, people who hold stakeholder theory believe that the survival and development of modern enterprises are not completely due to the capital investment of shareholders or the risk of enterprises' operations all borne by the shareholders. Instead, all stakeholders have contributed to the survival and development of enterprises and bear the risk of enterprise operations. Therefore, enterprises must also bear the social responsibility of stakeholders (Donaldson and Preston 1995). This view has been recognized by an increasing number of scholars, governments, the public, and enterprises.

(c) The Author(s), 2021. Open Access This article is licensed under a Creative Commons Attribution 4.0 International License, which permits use, sharing, adaptation, distribution and reproduction in any medium or format, as long as you give appropriate credit to the original author(s) and the source, provide a link to the Creative Commons licence, and indicate if changes were made. The images or other third party material in this article are included in the article's Creative Commons licence, unless indicated otherwise in a credit line to the material. If material is not included in the article's Creative Commons licence and your intended use is not permitted by statutory regulation or exceeds the permitted use, you will need to obtain permission directly from the copyright holder. To view a copy of this licence, visit http:// creativecommons.org/licenses/by/4.0/. 
Meanwhile, a large number of empirical studies have discussed a variety of factors that affect the behavior of CSR, including the institutional environment of enterprise operation, enterprise attributes, and the characteristics of enterprise managers (Aguinis and Glavas 2012), while there are few discussions about the influence of family. Although modern corporate systems have become the mainstream form of enterprises, the influence of family has not subsided. Many studies have found that the vast majority of enterprises in the world are still controlled by families. The combination of family and enterprise has a significant impact on the governance structure, business objectives, strategic choices, and corporate performance of enterprises (Chrisman et al. 2010; Kraus et al. 2011). Therefore, the social responsibility of family businesses is often shown by their own characteristics. One of the most representative characteristics is explained by the theory of socioemotional wealth (SEW), which suggests that compared with nonfamily businesses, family businesses pay more attention to socioemotional wealth and are more active in fulfilling CSR (Gómez-Mejía et al. 2011). This argument is supported by some empirical studies (Dyer and Whetten 2006; Zhou 2011). However, based on the hypothesis of rational man in neoclassical economics, some scholars believe that the family has a strong motive of self-interest and is willing to engage in many agential behaviors to maximize the family's interests at the cost of the interests of other stakeholders. Hence, the family business will not necessarily bear more social responsibility than other business forms (Gómez-Mejía et al. 2001; Le Breton-Miller and Miller 2009).

Therefore, there is controversy about the influence of family on CSR. One of the important reasons is that these studies do not pay attention to the different behavioral logics of families when they encounter different objects in fulfilling social responsibilities. Based on stakeholder theory, this article defines the objects of CSR as corporate stakeholders and divides them into contractual stakeholders and community stakeholders according to whether there is a formal contractual relationship between stakeholders and the enterprise. Since the interest demands of the two groups of stakeholders are not the same, the family in charge of the enterprise will decide how to perform the corresponding social responsibility based on different motives, resulting in the diversification of the influence of family involvement on CSR. Specifically, family involvement will improve CSR investment toward community stakeholders and restrain investment toward contractual stakeholders.

This article analyzes the above discussion by taking Chinese private enterprises as the research object. In the following section, we will first review the current research debate on the relationship between family involvement and CSR and then explain the diversification of the CSR of family businesses based on the distinction of different CSR objects. We will next introduce the data and research method and analyze the data results. Finally, based on the research results, we will further discuss the influence of Chinese families and the internal characteristics of Chinese society on the behavior of private enterprises in China.

\section{Literature review}

General studies of corporate social responsibility: stakeholder theory

As early as the 1930s, some scholars proposed the concept of corporate social responsibility. It is generally believed that Howard Bowen's publication of Social Business of the 
Businessman in 1953 was the beginning of modern research on CSR. In recent decades, there has been much research on CSR, especially in the 1980s and 1990s. The introduction of stakeholder theory has greatly expanded the empirical research on CSR and has become the mainstream theory in this field. One important reason is that stakeholder theory provides a convincing answer to the question of "Whom should the enterprise be responsible for?"

Before stakeholder theory, scholars generally accepted Carroll's "pyramid model of corporate social responsibility," which includes economic responsibility, legal responsibility, ethical responsibility, and charitable responsibility (Carroll 1991). Although this model has been widely applied, there are some imperfections. Carroll admitted that the meaning of "social" in CSR was vague, which did not clearly define who the company should be responsible for Carroll (1991). In this context, scholars who advocate stakeholder theory emphasize that enterprises comprise a collection of stakeholders and the entity for stakeholders to realize their interests. The survival and development of enterprises depend on the sustained support of stakeholders, so enterprises have the responsibility to generate value for these stakeholders (Freeman et al. 2013: 20-24). These stakeholders include any group or individual who affects or is affected by the company's goals (Freeman 2006: 2), such as shareholders, employees, customers, suppliers, communities, and governments. In this theoretical framework, the object of CSR is clearly defined as the stakeholders of the enterprise. This definition is rather conducive to CSR measurement, evaluation, and analysis (Clarkson 1995). Based on this theoretical progress, a large number of empirical studies on CSR have emerged.

Next, stakeholders are not only passive managers of CSR but also active influencers of CSR when they realize that corporate behavior has an impact on themselves. In general, these stakeholders can influence CSR on three levels (Aguinis and Glavas 2012). The first level is the institutional level. For instance, the government can encourage enterprises to invest in CSR by establishing a sound legal system and creating a good market environment so that CSR can bring positive feedback to enterprises (Christmann and Taylor 2006; Brammer et al. 2009; Li 2010). The second level is the organizational level; for example, consumers can punish a lack of CSR by boycotting corporate products (Sen and Bhattacharya 2001). The third level is the individual level at which the social identity and value system of management affect their cognition of CSR and ultimately affect CSR (Mudrack 2007; Muller and Kolk 2010; Gao et al. 2011). However, there are few empirical studies on the influence of family factors on CSR, especially in China. In fact, the family involved in the enterprise is often an important stakeholder of the enterprise. Their active participation in the operation and management of the enterprise is bound to have an important impact on CSR.

\section{Social responsibility of family business}

It is generally suggested by research on the family business that family involvement makes enterprises different from nonfamily enterprises (Kraus et al. 2011). If we focus on CSR among enterprise behaviors, the question is: Compared with nonfamily enterprises, what is the difference in family enterprises' social responsibility?

The theory of socioemotional wealth suggests that family business is different from nonfamily business in that family business specifies socioemotional wealth as its primary 
goal (Gómez-Mejía et al. 2011). This concept of socioemotional wealth has rich connotations, including sustaining the family's control and influence on the business, realizing family inheritance, maintaining a harmonious relationship among family members, supporting family members' organizational identity and commitment to the enterprise, and maintaining good social relations to increase the family's social capital (Berrone et al. 2012). In this sense, the main principle of decision-making regarding family business management is whether it can enhance the family's socioemotional wealth. Some studies have demonstrated that if a decision could reduce business risk but could not increase socioemotional wealth, family businesses would be more unlikely to adopt a decision than nonfamily businesses (Gómez-Mejía et al. 2011). For instance, some olive oil family businesses in southern Spain would not participate in enterprise cooperatives to maintain the control and influence of the family on the enterprise, although cooperation could reduce the operational risk of the enterprise (Gómez-Mejía et al. 2007).

On the basis of this theory, some scholars believe that CSR can establish a good corporate image and improve corporate reputation (Maignan et al. 1999; Brammer and Pavelin 2006; Li and Zhang 2010), which is exactly the socioemotional wealth that family businesses value (Zellweger et al. 2013). Therefore, family businesses would actively perform CSR to improve corporate reputation, even though the fulfillment of CSR could not improve the financial performance of enterprises. In contrast, nonfamily businesses pay more attention to economic performance and thus are less active in fulfilling social responsibility than family businesses. Some empirical studies have found that, compared with nonfamily businesses, the waste discharged by family businesses is less harmful to the environment (Berrone et al. 2010); the training investment and welfare level of employees in the family business are higher; the loyalty of employees is higher, and the turnover rate is lower (Reid and Harris 2002; Uhlaner et al. 2004); the overall social responsibility performance of the family business is also higher (Dyer and Whetten 2006; Zhou 2011).

However, under the framework of neoclassical economics, some scholars insist that there is no essential difference between the controlling family and the owners and managers in nonfamily enterprises. They are all rational people with the goal of maximizing their own economic interests. Moreover, since the controlling family holds more ownership of the enterprise, they would value the economic performance of the enterprise more than the general managers, even at the cost of other stakeholders, and they would not bear more social responsibility (Gómez-Mejía et al. 2001; Le Breton-Miller and Miller 2009). For example, studies have shown that the controlling family will seek private interests for their own family by sacrificing the interests of other shareholders (Morck and Yeung 2003). Once these family businesses control the economy of the whole country, they will also have a negative impact on the social welfare system. One study demonstrates that infrastructure, health care, and education services are generally worse in countries with many family-controlled large enterprises (Morck and Yeung 2004).

Some scholars believe that the ultimate goal of those behaviors, which seem to pursue socioemotional wealth, is to maximize family economic interests. The most typical example is the enterprise layoff. Studies reflected that, compared with nonfamily businesses, family businesses are less likely to lay off employees (Stavrou et al. 2007). 
However, if layoffs were inevitable, that is, keeping people on the payroll seriously hindered the development of enterprises, family business would lay off more employees for the protection of family economic interests than nonfamily business (Block 2010). Furthermore, the average payment of employees in family businesses is lower than that of nonfamily businesses, although family businesses are less likely to lay off employees (Bassanini et al. 2011). Therefore, the management decision of employment in the family business may not be made for the sake of accumulating socioemotional wealth, instead, for the consideration of strategic balance, that is, to ensure the stability of employment and reduce the employees' payment at the same time, which could reduce the operational risk of business.

In summary, theories of the social responsibility of family businesses are still controversial, and inconsistent results are generated by empirical research. On the one hand, this is due to controversial definitions of the family business (Chu 2004). Given that the vast majority of private enterprises are affected by families to different degrees, an increasing number of relevant studies have begun to abandon the dichotomy of "family business" and "nonfamily business" and regard family business as a variable of "family involvement" with continuous distribution to accurately examine the family influence on corporate behaviors and its dynamic changes ( $\mathrm{Li}$ and Zhu 2014). This article also adopts this approach.

On the other hand, more importantly, these studies generate controversial results about the motivation and logic of management decision-making in family businesses. The debate in the existing literature is whether to emphasize the social motivation or the economic motivation of family behavior. Deriving from their respective basic presuppositions, these two arguments deduce different research conclusions. This article suggests that the family is not a unitary organization. Instead, it is dual, especially in China, which is rooted in profound historical traditions. Ebrey (1984) pointed out that the traditional Chinese family is the incarnation of two ideal types. One is called a "clan" (zong, 宗), which originates from ancestor worship. It is the kinship network based on patrilineal relationships, seniority, and affinity. The kinship network inherited by the wife's eldest son is called the “major clan" ( a zong, 大宗), while other networks inherited by other sons are called the "minor clan" (xiao zong, 小宗). The other ideal type is called "family" (jia, 家), which is the political and economic unit inherited by the aristocrats in the pre-Qin period, similar to the "state" (guo, 国) of the feudal princes. The terms "a state with a thousand chariots" (qianshengzhiguo, 千乘 之国) and “a family with a hundred chariots" (baishengzhijia, 百乘之家) all describe the scale of these political and economic units. With the change of the times, especially the disintegration of the feudal system, the land was in ceaseless transaction and division. The family, based on land, eventually evolves into a kinship group of cohabitation and common wealth and becomes a basic economic unit in traditional society (Ebrey 1984). Compared with the clan, the family is a relatively independent and detached unit, since the basis of the family is land and property so that it could be "establishing a family," "dividing a family", and "destroying a family" by the acquisition, distribution, and consumption of land and property, respectively. This is not the same as the spread of a clan. The basis of the clan lies in its patrilineal lineage, and its source is a common ancestor. Although there is an increasing number of descendants, 
the birth of descendants reflects the proliferation or spread of the branches of the original clan. The original clan will only be continued and will not disintegrate.

In this sense, the goals of clan and family are different. The basic goal of the clan is to continue, including maintaining ancestor worship and sacrifice, maintaining harmonious relationships within the clan network, and ultimately maintaining the continuous spread and continuation of the clan. For this reason, the clan establishes a set of hierarchical ethical norms based on seniority and affinity and internalizes them through various ritual activities, which is exactly the goal of the whole traditional Chinese society. Therefore, the unity and continuation of the clan in traditional society can gain a reputation. The whole traditional society admires those "aristocratic families" and "living together for generations." However, the basic goal of "family" is maintaining existence. To survive better, families must continuously accumulate economic wealth. Although a family will pursue social reputation through charity, its foundation still lies in economic wealth (Ebrey 1984). Therefore, the "family," based on property, pursues economic goals, while the "clan," based on blood ties, emphasizes noneconomic goals. The real Chinese family is a mixture of "family" and "clan," which is consequently dual.

The duality of the family is introduced into business management behavior with the combination of family and business. The complex social responsibility of family businesses can be related to this concept. It is worth exploring how the family chooses its motive. In the context of Chinese social culture, this may relate to the specific object of behavior. As Fei (1998) pointed out, the structure of Chinese society is a "differential mode of association" (cha xu ge ju, 差序格局) (Fei 1998: 26).

Under this mode, people employ different standards to interact with people in different interpersonal relationships. Empirical research demonstrates that the concept of "cha xu ge ju" could be adopted to analyze Chinese enterprises. For instance, entrepreneurs in Chinese enterprises group organization members into different types according to closeness and loyalty and form different networks of "us" and establish trust patterns accordingly, which would ultimately affect the organizational behavior within the enterprise (Zheng 2005: 297-378). Similarly, this article argues that the motivation and behavior of families are different in the face of different behavior objects that have different relationships with the family. Regarding CSR behavior, the behavioral objects of families are other stakeholders of the enterprise. Due to the variety of enterprise stakeholders, this article would classify the stakeholders of enterprises first and infer the motivation of family behavior according to the relationships between family and different types of stakeholders to put forward specific assumptions about the relationship between family involvement and CSR.

\section{Stakeholders and social responsibility of family business Distinction of stakeholders}

Enterprises may have many stakeholders, but the requirements and objectives of these stakeholders are different, and their impacts on the enterprise's survival and development are distinctive. Therefore, the classification of stakeholders is an important step in enterprise management decisions (Chen and Jia 2004). After many attempts, Freeman (2006: 64-76) created a pioneering classification of stakeholders from three different perspectives: ownership, economic dependence, and social interests. Then, there 
are many other classification methods; for instance, stakeholders can be divided into contractual stakeholders and public stakeholders according to whether there is a trading contract relationship between the related groups and enterprises (Charkham 1992). Stakeholders can be divided into key stakeholders and secondary stakeholders according to the relationship closeness between the related groups and enterprises (Clarkson 1995). Stakeholders can be divided into identified stakeholders, prospective stakeholders, and potential stakeholders according to the three dimensions of legitimacy, power, and urgency (Mitchell et al. 1997). Although the ostensible classification dimensions of different scholars are different, the final classification result is basically consistent since the key criteria of classification are consistent, that is, whether the stakeholder has a direct impact on the enterprise's survival and development. Whether stakeholders could exert a direct impact depends on whether they have formal contractual relationships and direct economic transactions with the enterprise.

The theories of modern enterprises regard enterprises as legal entities composed of complex contracts (Jensen and Meckling 1976). This article mainly deals with formal market transaction contracts, including contracts between owners and operators, contracts between operators and employees, and contracts between enterprises as suppliers (or consumers) and consumers (or suppliers). These formal contracts constitute the fundamental economic activities of enterprises. In this sense, stakeholders who have formal transaction contract relationships with the enterprise are a part of the contract aggregation of the enterprise. Therefore, they can be called "contractual stakeholders," including shareholders, employees, suppliers, and customers. Without the continuous participation of these groups, the enterprise cannot be kept running. Those stakeholders who do not have formal contractual relationships are called community stakeholders, such as government, media, community, and the public. They do not carry out market transactions with enterprises directly, but they could indirectly affect the operation of enterprises or be affected by enterprise behavior. This article defines the social responsibility of contractual stakeholders as contractual social responsibility and the social responsibility of the community stakeholders of the enterprise as community social responsibility.

Due to the different relationships with the enterprise, the derivations of these two types of stakeholders require the enterprise to fulfill its social responsibility differently. Contractual stakeholders require social responsibility for the consideration of instrumentalism. Because contractual stakeholders often trade with enterprises in the market, CSR can reduce the transaction cost of these market transactions and help to maximize the economic benefits of enterprises (Jones 1995). In contrast, community stakeholders require social responsibility for normativity, emphasizing that CSR is a requirement of corporate ethics. Corporate ethics are established through social contracts to maintain the normal operation of the local social economy and society as a whole (Donaldson and Dunfee 1994; Donaldson and Preston 1995). Since the logic of different stakeholders to demands for social responsibility is different, the families involved in the enterprise would have different motives to perform social responsibility. Specifically, family members mainly decide whether they fulfill contractual social responsibility from the perspective of instrumentalism, that is, whether fulfilling their contractual social responsibility can substantially maximize their economic benefits. Community social 
responsibility is mainly driven by social motivation, and their priority is whether they could boost the family's socioemotional wealth (or social benefits). Under this premise, we further discuss the specific relationship between family involvement and CSR.

\section{Community stakeholder and social responsibility}

Based on the social contract, community stakeholders require the enterprise to fulfill the corresponding social responsibility, while the enterprise concerns the social benefits brought by fulfilling the social contract. Some studies show that although enterprises cannot improve their economic performance when they meet the expectations of community stakeholders, enterprises can obtain a positive evaluation that is the basis of the good reputation of enterprises (Dyer and Whetten 2006). From the perspective of socioemotional wealth theory, compared with general managers, family owners and managers pay more attention to socioemotional wealth, such as corporate reputation, so they are more willing to perform community social responsibility (Gómez-Mejía et al. 2011). Moreover, the deeper the family is involved in the enterprise, the stronger their motivation would be. This is because, first, based on the theory of organizational identity, the more closely individuals are related to the organization, the stronger the organizational identity they have (Dutton et al. 1994). Similarly, the deeper the family involvement is in the enterprise, the stronger the organizational identity family members would have, and the more likely they would regard the enterprise as the extension of the family and regard the enterprise reputation as the family reputation (Deephouse and Jaskiewicz 2013; Zellweger et al. 2013). Therefore, the deeper the family involvement is, the more active the family would participate in the contractual social responsibility that helps build their corporate image, improve their corporate reputation, and increase their family's socioemotional wealth.

Second, the operation of any enterprise faces many risks. When there is an economic crisis, the deeper the family is involved in the enterprise, the closer the relationship between the family economic property and the enterprise property is, and the greater the loss of the family economic property is. Given that family members would be inclined to transfer the enterprise from generation to generation and thus invest a significant amount of resources and affection in the enterprise, it would be more difficult for them to quickly eliminate the enterprise in a crisis than general managers (Dyer and Whetten 2006; Cennamo et al. 2012). Enterprise reputation, as moral capital, can help enterprises reduce the loss of economic value caused by improper operation (Godfrey 2005). In this sense, to protect their economic property from business damage, families would actively perform their community social responsibilities and improve their corporate reputation according to how deeply they are involved in the enterprise. In China, the legitimacy of private enterprises has been gradually established in recent years. Therefore, the social legitimacy of enterprises can also be improved by performing social responsibility, which is conducive to the survival and development of enterprises.

Furthermore, although family members tend to actively perform community social responsibility to accumulate socioemotional wealth, it may be resisted by nonfamily members in the enterprise. For example, nonfamily shareholders may be concerned that the fulfillment of community social responsibility would sacrifice the economic performance of the enterprise and damage their interests (Berrone et al. 2010; Gómez-Mejía 
et al. 2010). If family members wanted to encourage enterprises to actively fulfill their community social responsibility, they had to have the power to influence and decide the enterprise management policy. The deeper the family is involved in the enterprise, the higher the degree of their mastery of enterprise ownership and management power; thus, they are more likely to overcome the resistance of nonfamily members to ensure the implementation of corporate community social responsibility (Deephouse and Jaskiewicz 2013).

To sum up, we can obtain the first hypothesis.

Hypothesis 1 The deeper the family is involved in the enterprise, the more social responsibility the enterprise performs toward community stakeholders.

\section{Contractual stakeholder and social responsibility}

Different from community stakeholders, contractual stakeholders have a formal contractual relationship with the enterprise. From the theory of modern enterprise, the enterprise cannot be regarded as owned by capital; instead, it is the contractual relationship aggregate among these contractual stakeholders, since all contractual stakeholders have invested specified assets into the enterprise and bear the corresponding risks (Fama 1980). The viability of this aggregate depends on all contractual stakeholders. Theoretically, the management of the enterprise is comprised of contractual stakeholders, but they could also be regarded as contractual agents of the enterprise since they sign contracts with other stakeholders directly or indirectly on behalf of the enterprise and have a "strategic position" in the key decisions of the enterprise (Hill and Jones 2010). In other words, enterprise management is entrusted by the whole contract aggregate to manage these contracts, whose goal is to improve the viability of the enterprise and maximize the enterprise's economic benefits (Freeman and Evan 1990). In this sense, enterprise management establishes principal-agent relationships with other contractual stakeholders. Some scholars regard this as a kind of generalized principal-agent relationship, different from the classical principal-agent relationship (Hill and Jones 2010). However, no matter what kind of agency relationship it is, some conditions would lead to agency problems. In this case, it refers to the interest inconsistency, information asymmetry, and power inequality between enterprise management and other contractual stakeholders. Will this cause a principal-agent problem? Does management maximize its own interests by reducing the social responsibility investment of other contractual stakeholders in the case of CSR? The current research is still controversial.

On the one hand, agency theory suggests that agents with managerial power and information advantage will pursue their own interests at the expense of the principal. They have a natural tendency of self-service and are guided by agent orientation, so they will sacrifice the interests of other contractual stakeholders to maximize their own (Jensen and Meckling 1976). In contrast to the agency hypothesis of agency theory, stewardship theory suggests that managers are driven not only by a selfinterest motive but also by a collectivism tendency. They pursue the maximization of enterprise performance, meet the interest requirements of all relevant parties, and maximize individual benefits under the premise of maximizing the performance of 
enterprises (Davis et al. 1997). Comparatively, the manager as an agent considers the maximization of economic benefits in the short term. Therefore, the strategy of minimizing potential cost is adopted. The contractual social responsibility should be reduced as much as possible, as the contractual social responsibility of the enterprise is regarded as a short-term cost. However, the manager as a steward would consider contractual social responsibility as an investment in the maximum potential longterm performance. By maintaining good relationships with contractual stakeholders, managers encourage them to make greater efforts for business development (Corbetta and Salvato 2004; Déniz and Suarez 2005). Therefore, what factors affect the role of managers?

Granovetter (1985) believes that economic behavior is embedded in a specific and current network of social relations. Some scholars have pointed out that the social embeddedness of enterprise managers will lead them to choose agent or steward behavior. When managers are embedded in a relationship network between different groups, they have the strongest sense of identity with the most closely related groups and pursue the best interests for the group (Ashforth and Johnson 2001). In this case, unlike relatively independent managers, family managers in an enterprise are embedded in the family and the enterprise simultaneously. The degree to which they are embedded in the family relationship will affect their role in the enterprise. Generally, family members develop common interests, cognition, and values through long-term communication and coresidence. They thus form a strong sense of identity with the family and take the family interests as the highest goal. Compared with general managers, family members are more likely to sacrifice the interests of other contractual stakeholders to pursue family interests. However, family members in some enterprises do not have a strong sense of family identity due to poor family relationships. They would be more loyal to the enterprise and play the role of steward (Le Breton-Miller et al. 2011).

In China, family exists as the most basic social structure. The profound accumulation of family culture greatly influences people's psychological disposition and behavior, which is unparalleled with other family cultures (Chu 2000). Many scholars have also found that trust between Chinese people is limited, and trust mainly exists in the family relationship network based on bloodlines and kinship (Fukuyama 2001: 7083), while outsiders are excluded from this trust. A typical example is that nepotism is more common in Chinese enterprises, and trust in contractual managers is limited (Li 2002, 2003). Therefore, this article believes that in China's private enterprises, family owners and managers have a strong sense of family identity due to cohesion and special trust within the family. Compared with other general managers, they may have a stronger tendency to act as agents; that is, they are more likely to reduce contractual social responsibility investment for the sake of maximizing the family's economic interests. Moreover, with an increase in the level of family involvement, the less supervised the family members are, and the stronger their agency ability is, the less likely they are to fulfill the contractual social responsibility of the enterprise. Therefore, the second hypothesis can be drawn.

Hypothesis 2 The deeper the family is involved in the enterprise, the less social responsibility the enterprise performs toward contractual stakeholders. 


\section{Research methods}

Data

The data are from the Ninth National Sample Survey of Private Enterprises conducted by the private enterprise research group in the first half of $2010{ }^{1}$ The survey first selects the sample of private enterprises according to the scale structure and industry structure of enterprises from the China Statistical Yearbook and surveys local business associations and bureaus. The survey objects are the legal representatives or entrepreneurs of private enterprises. The survey covers various industries, sizes, and types of enterprises in 31 provinces, autonomous regions, and municipalities. Therefore, the sample of this study is representative of China's private enterprises. In this survey, 4610 valid questionnaires were collected, and 2734 were selected after excluding the cases with missing data.

\section{Variables}

\section{Dependent variable}

This study distinguishes the object of CSR as community stakeholders and contractual stakeholders. CSR to community stakeholders is measured by charitable donations and pollution control investments; CSR to contractual stakeholders is measured by staff training investments and staff social insurance investments. First, the absolute amount of social responsibility investment (unit: yuan) is used as the dependent variable to investigate the influence of family involvement in CSR. Second, the intensity of social responsibility investment is the dependent variable, which is the proportion of social responsibility investment in sales (unit: 10,000 yuan). To make the dependent variable normally distributed, I include these indicators in the model using the logarithm.

\section{Independent variable}

The core independent variable of this study is the degree of family involvement. We use the degree of family ownership and family managerial power to measure the degree of family involvement. Family ownership refers to the ratio of the ownership held by family members to the total ownership of the enterprise. Family managerial power refers to the ratio of the number of family managers to the number of all enterprise managers. The managers of the enterprise refer to the people in charge in each department. If a manager shared the bloodline or had a marital relationship with the owner, the manager was categorized as the family manager; otherwise, he or she was categorized as the general manager.

\section{Control variables}

The control variables of this study mainly include the characteristics of entrepreneurs and the characteristics of enterprises.

The individual attributes of business owners mainly include gender, education, and political connections. In this study, the education level of entrepreneurs is set as a dummy variable, which is assigned as 1 for the college, undergraduate, or postgraduate level and 0 for

\footnotetext{
1 The research group is composed of the United Front Work Department of the CPC Central Committee, the All-China Federation of Commerce, the State Administration of Commerce and Administration, and the China Private Economy Research Association.
} 
senior high school and below. According to the general state of affairs, the most important way for business owners to participate in politics is to be elected as a representative to the National People's Congress or become a member of the Chinese People's Political Consultative Conference, which is regarded as a specific indicator of the political connections of business owners. In this study, if a business owner was a representative of the National People's Congress or a member of the Chinese People's Political Consultative Conference, he or she would be classified as having political connections, and the value would be set to 1 ; otherwise, it would be set to 0 .

The characteristics of the enterprise include the industry where the enterprise is located, the foundation date of the enterprise, the region where the enterprise is located, and the scale and performance of the enterprise. Since the questionnaire asks enterprises to list three main business industries, we control the impact of the enterprise industry with two variables. One is whether the enterprises are engaged in the manufacturing industry, and the other is whether the enterprises are engaged in multiple industries, both of which are dummy variables in the model. The foundation date of an enterprise is calculated by subtracting the opening year from the survey year. If the foundation date of an enterprise was less than one year, it was counted as one year. We divide the locations of enterprises into the east, the central, and the west according to general criteria and set it as a dummy variable in the model with the east as the reference. The scale of an enterprise is measured by two indicators. One is the average annual number of employees employed by the enterprise, and the other is the sales volume of the enterprise (10,000 yuan). The logarithm of enterprises scale is included in the model since there are great discrepancies among enterprises. In this study, the net profit rate of sales is the index of enterprise performance, the net profit rate of sales $=($ net profit/sales) $* 100 \%$, and the negative net profit is set as 0 (Table 1$)$.

\section{Model}

This study uses the Tobit model to explore the relationship between family involvement and CSR investment. The Tobit model is a model with dependent variable values under certain constraints. It extends from the original structural model to a time series model, panel data model, and nonparametric model (Zhou and Li 2012). This study uses the standard Tobit model, suitable for dealing with data with many deleted values of dependent variables. The dependent variable has deleted many values since CSR investment cannot be negative, and many enterprises have no investment in CSR. When the dependent variable has many values deleted, the parameters estimated by the least square method are biased and inconsistent. Therefore, the general linear regression method is unsuitable, while the Tobit model can solve this problem through maximum likelihood estimation. Compared with the logistic model, the Tobit model could take full advantage of the information of "whether the enterprise fulfills its social responsibility" and "the investment in social responsibility is different among enterprises." The Tobit model is set as follows:

$$
\begin{gathered}
y_{i}^{*}=\alpha+\beta_{j} x_{i j}+\lambda_{k} z_{i k}+\varepsilon_{i} \\
y_{i}=\left\{\begin{array}{cc}
y_{i}^{*} \text { if } y_{i}^{*}>0 \\
0 & \text { if } y_{i}^{*} \leq 0
\end{array}\right.
\end{gathered}
$$

The dependent variable $y_{i}$ is the investment in CSR, which is nonnegative, and $y_{i}^{*}$ is the latent variable. $z_{i k}$ is the control variable of the model, which represents a series of 
Table 1 Statistical description of main variables

\begin{tabular}{|c|c|c|c|c|c|}
\hline Variable & Sample size & Mean & $\begin{array}{l}\text { Standard } \\
\text { deviation }\end{array}$ & Minimum value & Maximum value \\
\hline \multicolumn{6}{|l|}{ Dependent variable } \\
\hline Charitable donation (yuan, logarithm) & 2563 & 7.41 & 4.32 & 0 & 16.12 \\
\hline $\begin{array}{l}\text { Pollution control investment (yuan, } \\
\text { logarithm) }\end{array}$ & 2603 & 3.50 & 5.10 & 0 & 16.38 \\
\hline $\begin{array}{l}\text { Social insurance investment (yuan, } \\
\text { logarithm) }\end{array}$ & 1947 & 7.88 & 5.67 & 0 & 16.85 \\
\hline $\begin{array}{l}\text { Employee training investment (yuan, } \\
\text { logarithm) }\end{array}$ & 2649 & 6.71 & 5.00 & 0 & 15.04 \\
\hline Charity sales ratio (logarithm) & 2561 & 2.14 & 1.82 & 0 & 9.32 \\
\hline Pollution control sales ratio (logarithm) & 2602 & 1.06 & 1.84 & 0 & 9.79 \\
\hline Social security sales ratio (logarithm) & 1946 & 2.96 & 2.38 & 0 & 9.47 \\
\hline Training sales ratio (logarithm) & 2649 & 1.94 & 1.83 & 0 & 7.91 \\
\hline \multicolumn{6}{|l|}{ Independent variable } \\
\hline Family ownership involvement & 2734 & 0.80 & 0.29 & 0 & 1 \\
\hline $\begin{array}{l}\text { Involvement of family management } \\
\text { rights }\end{array}$ & 2734 & 0.26 & 0.33 & 0 & 1 \\
\hline \multicolumn{6}{|l|}{ Control variable } \\
\hline Gender (1 = male) & 2734 & 0.86 & 0.34 & 0 & 1 \\
\hline Education ( $1=$ University and above) & 2734 & 0.61 & 0.49 & 0 & 1 \\
\hline Political connections ( $1=$ yes) & 2734 & 0.48 & 0.50 & 0 & 1 \\
\hline Diversity ( 1 =yes) & 2734 & 0.23 & 0.42 & 0 & 1 \\
\hline Manufacturing ( $1=$ yes $)$ & 2734 & 0.43 & 0.50 & 0 & 1 \\
\hline Corporate history & 2734 & 8.80 & 4.60 & 1 & 21 \\
\hline \multicolumn{6}{|l|}{ Region } \\
\hline Eastern (1 =yes) & 2734 & 0.56 & 0.50 & 0 & 1 \\
\hline Central (1=yes) & 2734 & 0.24 & 0.43 & 0 & 1 \\
\hline Western ( $1=$ yes $)$ & 2734 & 0.19 & 0.39 & 0 & 1 \\
\hline Number of employees (logarithm) & 2734 & 4.05 & 1.56 & 0.69 & 9.20 \\
\hline Sales (ten thousand yuan, logarithm) & 2734 & 6.72 & 2.25 & 0.41 & 15.19 \\
\hline Sales margin & 2734 & 10.89 & 16.38 & 0 & 100 \\
\hline
\end{tabular}

variables of the characteristics of business owners and enterprises. $\lambda_{K}$ represents the coefficient of these variables. $x_{i j}$ is the variable of family involvement, referring to family ownership involvement and family managerial power involvement, respectively, and $\beta_{j}$ represents the coefficient of the two variables. $\alpha$ is the constant term of the model. $\varepsilon_{i}$ is the error term, which follows the normal distribution with a mean value of 0 and a variance of $\sigma^{2}$.

\section{Analysis}

Model 1 shows the impact of family involvement on the absolute amount of CSR (Table 2). First, the influence of family involvement on corporate community social responsibility includes that, first, the political connections of business owners have a positive impact on corporate philanthropy and pollution control investment, which is consistent with most previous studies (Liang et al. 2010; Gao et al. 2011); the investment of enterprises in the central and western regions is not as large as that in the eastern regions, which may be related to the better market environment in the eastern 
Table 2 Maximum likelihood estimation of the absolute amount of family involvement and CSR investment

\begin{tabular}{|c|c|c|c|c|}
\hline & \multirow{3}{*}{$\begin{array}{l}\text { Model } 1.1 \\
\text { Charitable donation } \\
\text { B/S.E. }\end{array}$} & \multirow{3}{*}{$\begin{array}{l}\text { Model } 1.2 \\
\text { Pollution } \\
\text { control } \\
\text { investment } \\
\text { B/S.E. }\end{array}$} & \multirow{3}{*}{$\begin{array}{l}\text { Model } 1.3 \\
\text { Social } \\
\text { security } \\
\text { investment } \\
\text { B/S.E. }\end{array}$} & \multirow{3}{*}{$\begin{array}{l}\text { Model } 1.4 \\
\text { Training investment } \\
\text { B/S.E. }\end{array}$} \\
\hline & & & & \\
\hline & & & & \\
\hline Gender (1 = male) & $\begin{array}{l}-0.069 \\
(0.275)\end{array}$ & $\begin{array}{l}1.601^{*} \\
(0.797)\end{array}$ & $\begin{array}{l}-1.100^{* *} \\
(0.418)\end{array}$ & $\begin{array}{l}0.278 \\
(0.364)\end{array}$ \\
\hline $\begin{array}{l}\text { Education ( } 1=\text { University and } \\
\text { above) }\end{array}$ & $\begin{array}{l}0.266 \\
(0.199)\end{array}$ & $\begin{array}{l}-0.858 \\
(0.531)\end{array}$ & $\begin{array}{l}1.358^{* * *} \\
(0.333)\end{array}$ & $\begin{array}{l}0.730^{* *} \\
(0.262)\end{array}$ \\
\hline Political connection ( $1=$ yes) & $\begin{array}{l}2.037^{* * *} \\
(0.208)\end{array}$ & $\begin{array}{l}1.227^{*} \\
(0.556)\end{array}$ & $\begin{array}{l}0.114 \\
(0.326)\end{array}$ & $\begin{array}{l}0.845^{* *} \\
(0.264)\end{array}$ \\
\hline Diversity ( $1=$ yes $)$ & $\begin{array}{l}0.779^{* * *} \\
(0.208)\end{array}$ & $\begin{array}{l}-0.361 \\
(0.571)\end{array}$ & $\begin{array}{l}-0.555 \\
(0.357)\end{array}$ & $\begin{array}{l}0.529^{*} \\
(0.266)\end{array}$ \\
\hline Manufacturing ( $1=$ yes $)$ & $\begin{array}{l}-0.569^{* *} \\
(0.207)\end{array}$ & $\begin{array}{l}4.445^{* * *} \\
(0.519)\end{array}$ & $\begin{array}{l}0.832^{* *} \\
(0.312)\end{array}$ & $\begin{array}{l}0.158 \\
(0.247)\end{array}$ \\
\hline Corporate history & $\begin{array}{l}0.089^{* * *} \\
(0.021)\end{array}$ & $\begin{array}{l}0.020 \\
(0.058)\end{array}$ & $\begin{array}{l}0.077^{*} \\
(0.035)\end{array}$ & $\begin{array}{l}0.007 \\
(0.028)\end{array}$ \\
\hline \multicolumn{5}{|l|}{ Region (reference item: Eastern) } \\
\hline Central & $\begin{array}{l}-0.465^{*} \\
(0.235)\end{array}$ & $\begin{array}{l}-1.186^{+} \\
(0.611)\end{array}$ & $\begin{array}{l}-2.432^{* * *} \\
(0.382)\end{array}$ & $\begin{array}{l}-0.505^{+} \\
(0.300)\end{array}$ \\
\hline Western & $\begin{array}{l}-0.716^{* *} \\
(0.256)\end{array}$ & $\begin{array}{l}0.225 \\
(0.668)\end{array}$ & $\begin{array}{l}-1.165^{* *} \\
(0.396)\end{array}$ & $\begin{array}{l}0.236 \\
(0.311)\end{array}$ \\
\hline Number of employees & $\begin{array}{l}0.663^{* * *} \\
(0.095)\end{array}$ & $\begin{array}{l}2.535^{* * *} \\
(0.254)\end{array}$ & $\begin{array}{l}0.972^{* * *} \\
(0.149)\end{array}$ & $\begin{array}{l}1.478^{* * *} \\
(0.122)\end{array}$ \\
\hline Sales & $\begin{array}{l}0.455^{* * *} \\
(0.072)\end{array}$ & $\begin{array}{l}0.518^{* *} \\
(0.187)\end{array}$ & $\begin{array}{l}1.127^{* * *} \\
(0.111)\end{array}$ & $\begin{array}{l}0.687^{* * *} \\
(0.092)\end{array}$ \\
\hline Sales margin & $\begin{array}{l}0.030^{* * *} \\
(0.006)\end{array}$ & $\begin{array}{l}0.063^{* * *} \\
(0.016)\end{array}$ & $\begin{array}{l}-0.014 \\
(0.012)\end{array}$ & $\begin{array}{l}0.022^{* *} \\
(0.008)\end{array}$ \\
\hline $\begin{array}{l}\text { Involvement of family owner- } \\
\text { ship }\end{array}$ & $\begin{array}{l}0.784^{*} \\
(0.360)\end{array}$ & $\begin{array}{l}-1.263 \\
(0.860)\end{array}$ & $\begin{array}{l}-1.395^{* *} \\
(0.492)\end{array}$ & $\begin{array}{l}0.008 \\
(0.409)\end{array}$ \\
\hline $\begin{array}{l}\text { Involvement of family manage- } \\
\text { ment rights }\end{array}$ & $\begin{array}{l}0.728^{*} \\
(0.300)\end{array}$ & $\begin{array}{l}1.969^{*} \\
(0.834)\end{array}$ & $\begin{array}{l}-1.886^{* * *} \\
(0.554)\end{array}$ & $\begin{array}{l}-2.044^{* * *} \\
(0.431)\end{array}$ \\
\hline Constant term & $\begin{array}{l}-1.535^{* *} \\
(0.568)\end{array}$ & $\begin{array}{l}-20.514^{* * *} \\
(1.500)\end{array}$ & $\begin{array}{l}-2.933^{* *} \\
(0.902)\end{array}$ & $\begin{array}{l}-6.198^{* * *} \\
(0.719)\end{array}$ \\
\hline Sample size & 2563 & 2603 & 1947 & 2649 \\
\hline Interception number on the left & 555 & 1676 & 634 & 882 \\
\hline-2 Log Likelihood & $13,035.16$ & 8572.64 & 9584.33 & $12,641.36$ \\
\hline
\end{tabular}

${ }^{+} p<0.1, * p<0.05,{ }^{* *} p<0.001,{ }^{* * *} p<0.001$ (2) robust standard error in parentheses

regions (Zhou et al. 2012); the larger the scale of the enterprise is, and the better the economic performance of the enterprise is, the more social responsibility the enterprise will undertake.

It is worth noting that although manufacturing enterprises invest more in pollution control, they perform poorer in charitable donations, which may be because compared with other enterprises, manufacturing enterprises discharge more pollutants and thus invest more in pollution control.

Second, the coefficient of the degree of family ownership and family managerial power is significantly positive for the charity donations of enterprises, which means that the amount of charity donations of enterprises will increase by $0.78 \%$ and $0.73 \%$, respectively, with one percentage increase in the degree of family ownership and 
family management power. However, only family managerial power has a significant impact on enterprise pollution control investment. Enterprise pollution control investment will increase by $1.97 \%$, with one percentage increase in the degree of family managerial power involvement. Generally, the result supports Hypothesis 1 that the deeper the family is involved in the enterprise, the more social responsibility the enterprise performs toward community stakeholders.

Second, regarding the contractual social responsibility of enterprises, on the one hand, the influence of the family involvement level has changed significantly. Both family ownership and family managerial power have a significant negative influence on corporate social insurance investment; that is, the deeper the family involvement is, the less the corporate social insurance investment is. Family ownership does not have a significant impact on corporate staff training investment, but family managerial power has a significant negative impact on it. The training investment of enterprise staff will decrease by approximately $2 \%$ with every one percentage point increase in family managerial power.

On the other hand, the influence of political connections, enterprise location, enterprise size, and enterprise performance is consistent with Model 1.1 and Model 1.2, which reflects that the impact of these variables on CSR behavior will not change with the nature of stakeholders. In addition, the results also show that the education level of entrepreneurs has a positive impact on social security investment and training investment, while it has no significant impact on community social responsibility. This may be because the higher the education level of entrepreneurs is and the greater they understand CSR, the greater they hope to encourage employees to work actively by increasing the investment of contractual stakeholders to improve the economic performance of enterprises.

The dependent variable of Model 2 is CSR investment. By examining the influence of family involvement on CSR investment, Model 2 can test the robustness of the above analysis (see Table 3). Through comparison, it can be found that the variables of sales all change from positive to negative because the dependent variable is the ratio of CSR investment to sales. Moreover, except for the significant change of the coefficients of individual variables in the control variables, the properties (plus-minus sign) and significance of the coefficients of other variables have no significant change, which indicates that the previous results are reliable. As far as this study is concerned, family involvement has a positive impact on corporate philanthropy and pollution control investment and has a negative impact on social insurance investment and training investment. In other words, the deeper the family involvement is, the more social responsibility the enterprise performs to its community stakeholders, and the less social responsibility it performs to its contractual stakeholders. This further verifies Hypothesis 1 and Hypothesis 2.

\section{Conclusion and discussion}

Based on the data from the Ninth National Survey of Private Enterprises, this research finds a seemingly paradoxical relationship between family involvement and CSR. On the one hand, family involvement will increase CSR investment to community stakeholders; on the other hand, family involvement will inhibit CSR investment to contractual stakeholders. The reason for this result is that the family itself has a complicated logic of 
Table 3 The biggest likelihood estimate of family involvement and intensity of CSR input

\begin{tabular}{|c|c|c|c|c|}
\hline & Model 2.1 & Model 2.2 & Model 2.3 & Model 2.4 \\
\hline & Charitable donation & $\begin{array}{l}\text { Pollution } \\
\text { control } \\
\text { investment }\end{array}$ & $\begin{array}{l}\text { Social } \\
\text { security } \\
\text { investment }\end{array}$ & Training investment \\
\hline & B/S.E. & B/S.E. & B/S.E. & B/S.E. \\
\hline Gender (1 = male) & $\begin{array}{l}0.005 \\
(0.122)\end{array}$ & $\begin{array}{l}0.565^{+} \\
(0.305)\end{array}$ & $\begin{array}{l}-0.530^{*} \\
(0.220)\end{array}$ & $\begin{array}{l}0.075 \\
(0.160)\end{array}$ \\
\hline $\begin{array}{l}\text { Education ( } 1=\text { University and } \\
\text { above) }\end{array}$ & $\begin{array}{l}0.158^{+} \\
(0.088)\end{array}$ & $\begin{array}{l}-0.393^{+} \\
(0.202)\end{array}$ & $\begin{array}{l}0.769^{* * *} \\
(0.167)\end{array}$ & $\begin{array}{l}0.310^{* *} \\
(0.111)\end{array}$ \\
\hline Political connection (1 =yes) & $\begin{array}{l}0.955^{* * *} \\
(0.088)\end{array}$ & $\begin{array}{l}0.516^{*} \\
(0.210)\end{array}$ & $\begin{array}{l}0.025 \\
(0.161)\end{array}$ & $\begin{array}{l}0.410^{* * *} \\
(0.110)\end{array}$ \\
\hline Diversity ( 1 =yes) & $\begin{array}{l}0.448^{* * *} \\
(0.094)\end{array}$ & $\begin{array}{l}-0.115 \\
(0.213)\end{array}$ & $\begin{array}{l}-0.197 \\
(0.175)\end{array}$ & $\begin{array}{l}0.264^{*} \\
(0.115)\end{array}$ \\
\hline Manufacturing ( $1=$ yes $)$ & $\begin{array}{l}-0.386^{* * *} \\
(0.089)\end{array}$ & $\begin{array}{l}1.591^{* * *} \\
(0.198)\end{array}$ & $\begin{array}{l}0.373^{*} \\
(0.155)\end{array}$ & $\begin{array}{l}0.003 \\
(0.103)\end{array}$ \\
\hline Corporate history & $\begin{array}{l}0.050^{* * *} \\
(0.010)\end{array}$ & $\begin{array}{l}0.008 \\
(0.022)\end{array}$ & $\begin{array}{l}0.036^{*} \\
(0.017)\end{array}$ & $\begin{array}{l}0.006 \\
(0.012)\end{array}$ \\
\hline \multicolumn{5}{|l|}{ Region (reference item: Eastern) } \\
\hline Central & $\begin{array}{l}-0.325^{* *} \\
(0.103)\end{array}$ & $\begin{array}{l}-0.392^{+} \\
(0.231)\end{array}$ & $\begin{array}{l}-1.329^{* * *} \\
(0.190)\end{array}$ & $\begin{array}{l}-0.159 \\
(0.127)\end{array}$ \\
\hline Western & $\begin{array}{l}-0.358^{* *} \\
(0.114)\end{array}$ & $\begin{array}{l}0.205 \\
(0.259)\end{array}$ & $\begin{array}{l}-0.760^{* * *} \\
(0.199)\end{array}$ & $\begin{array}{l}0.112 \\
(0.134)\end{array}$ \\
\hline Number of employees & $\begin{array}{l}0.356^{* * *} \\
(0.041)\end{array}$ & $\begin{array}{l}0.983^{* * *} \\
(0.098)\end{array}$ & $\begin{array}{l}0.596^{* * *} \\
(0.073)\end{array}$ & $\begin{array}{l}0.667^{* * *} \\
(0.051)\end{array}$ \\
\hline Sales & $\begin{array}{l}-0.363^{* * *} \\
(0.032)\end{array}$ & $\begin{array}{l}-0.109 \\
(0.071)\end{array}$ & $\begin{array}{l}-0.062 \\
(0.057)\end{array}$ & $\begin{array}{l}-0.229^{* * *} \\
(0.040)\end{array}$ \\
\hline Sales margin & $\begin{array}{l}0.016^{* * *} \\
(0.003)\end{array}$ & $\begin{array}{l}0.026^{* * *} \\
(0.007)\end{array}$ & $\begin{array}{l}-0.008 \\
(0.007)\end{array}$ & $\begin{array}{l}0.014^{* *} \\
(0.004)\end{array}$ \\
\hline $\begin{array}{l}\text { Involvement of Family owner- } \\
\text { ship }\end{array}$ & $\begin{array}{l}0.465^{* *} \\
(0.148)\end{array}$ & $\begin{array}{l}-0.389 \\
(0.320)\end{array}$ & $\begin{array}{l}-0.765^{* *} \\
(0.249)\end{array}$ & $\begin{array}{l}0.090 \\
(0.172)\end{array}$ \\
\hline $\begin{array}{l}\text { Involvement of family manage- } \\
\text { ment rights }\end{array}$ & $\begin{array}{l}0.232^{+} \\
(0.140)\end{array}$ & $\begin{array}{l}0.651^{*} \\
(0.321)\end{array}$ & $\begin{array}{l}-0.962^{* * *} \\
(0.279)\end{array}$ & $\begin{array}{l}-0.878^{* * *} \\
(0.186)\end{array}$ \\
\hline Constant term & $\begin{array}{l}1.490^{* * *} \\
(0.257)\end{array}$ & $\begin{array}{l}-6.092^{* * *} \\
(0.558)\end{array}$ & $\begin{array}{l}1.348^{* *} \\
(0.469)\end{array}$ & $\begin{array}{l}-0.327 \\
(0.314)\end{array}$ \\
\hline Sample size & 2561 & 2602 & 1946 & 2649 \\
\hline Interception number on the left & 555 & 1676 & 634 & 882 \\
\hline-2 Log Likelihood & 9587.51 & 6711.40 & 7750.30 & 9562.56 \\
\hline
\end{tabular}

${ }^{+} p<0.1,{ }^{*} p<0.05,{ }^{* *} p<0.001,{ }^{* * *} p<0.001$ (2) robust standard error in parentheses

behavior. Under the influence of the "differential mode of association," the family adopts different logics to interact with objects in different relationships. When the family is involved in the enterprise, this mode of action is also brought into enterprise management. If the enterprise was regarded as an aggregate of formal contracts among contractual stakeholders, the controlling family in the enterprise would become the agent of contract management because of its special strategic position. They would pursue the maximization of their own economic interests like other contractual stakeholders. In the Chinese cultural context, these family managers tend to act as agents rather than stewards and sacrifice the interests of other contractual stakeholders to maximize their own economic interests. In contrast, the social relationship between the controlling family and community stakeholders is relatively loose. The focus of the family is not to compete for economic interests but mainly to enhance socioemotional wealth. Compared with 
general managers, family members pay more attention to corporate reputation, and they actively perform their social responsibilities to community stakeholders.

The results of this research also demonstrate that different indicators of family involvement do not have a consistent impact on CSR, and "family managerial power" has a significant impact on four kinds of CSR, while "family ownership" only has an impact on donations and employee social insurance investment. Therefore, the influence of "family managerial power" may have a stronger influence. The author suggests that "family ownership" makes the family have a certain connection with the enterprise, which impacts the behavioral motive of the family. However, "family managerial power" provides the controlling family with a direct impact on the operation and management of the enterprise, which is more important when the interests of other stakeholders are sacrificed.

In the research of Chinese enterprises, scholars usually pay attention to the organizational behavior of paternalism (or panfamilism) in family enterprises, which is regarded as distinctively Confucian (Chu 2004). However, the results show that even though paternalism does exist in Chinese family enterprises, it is questionable whether it could spread beyond the family. This study does not find evidence to support the family's special treatment to other contractual stakeholders. In fact, as mentioned above, the traditional Chinese family is a mixture of two different ideal models, namely the "clan" as a carrier of bloodline and ethical norms and the "family" as a social and economic unit (Ebrey 1984). The former pays more attention to the family's socioemotional wealth, while the latter pays more attention to the accumulation of economic wealth. Families involved in modern business also inherit this duality, but research could not only emphasize the "clan" as a prominent Confucian pattern but neglect the economic mode of "family." In fact, under the special relationship structure in China, families adopt different behavior logics to interact with different objects. Moreover, these two kinds of logic are not opposite and may be complementary. In traditional China, family wealth is the material basis of family ancestor worship and family social reputation; in modern family enterprises, families accumulate their own economic wealth at the expense of contractual stakeholders, whose wealth would be given back to society and gain a better family reputation. In this sense, we can call the families involved in Chinese private enterprises "self-centered philanthropists."

Furthermore, family duality not only alters with the object but also changes with the development of the enterprise. The research finds that the longer the business history is and the larger the enterprise scale is, the greater the social responsibility investment of the enterprise is. This may be because the main purpose of early entrepreneurial activities is to maintain the economic unit of the "family" and to promote the living standard of the family. In the immature market economy environment in China, the development of enterprises usually depends on the family. Therefore, in the early stage of entrepreneurship, the owners of enterprises do not have strong noneconomic goals and rely heavily on family contacts, which makes enterprises rarely fulfill various social responsibilities. With the development of the enterprise, the influence of clans on enterprise owners is becoming increasingly obvious. In other words, when basic economic demands are satisfied, the social motivation of "bring glory on one's ancestors" and "be benevolent" may become important internal motivations for enterprise development, which makes the enterprise owners actively perform the community 
social responsibility of the enterprise. Meanwhile, with the expansion of the enterprise scale and the complication of the organization structure, the influence of family members on business operations is diluted. To motivate nonfamily employees in the enterprise, enterprises will also raise contractual social responsibility investment.

A further question is why Chinese families prefer to act as agents rather than stewards in enterprises. Given the characteristics of Chinese families, this article argues that this is because family connections are the closest and most important relationship for Chinese people and have the strongest sense of identity. It is noted that other factors may also have an impact on it. First, China's market economic environment is far from perfect, especially because the legitimacy of the private economy has been questioned and often plundered by the government. It is thus not easy for business owners to form a long-term strategic vision. They want to accumulate wealth as soon as possible. Even if the policy changed, they could transfer wealth as soon as possible. Second, at present, the social understanding of CSR is relatively limited. Many people regard charity donations and environmental protection as typical social responsibilities. Therefore, society hardly supervises the performance of corporate contractual social responsibility. Business owners do not have a strong sense of social responsibility and only treat CSR as an expense rather than an approach to promote enterprise performance by managing social responsibility. Therefore, to promote the fulfillment of CSR, criticism against private enterprises from the perspective of family self-interest is not enough since the influence of family involvement on CSR is diverse. The economic environment for the survival and development of enterprises needs to be improved to advance the understanding and recognition of CSR in society as a whole.

Finally, the social responsibility of family businesses discussed in this article is based on the duality of traditional Chinese families and China's unique social and economic environment. Whether the results can be applied to foreign family businesses needs further research. In contrast, given that families generally influence Chinese private enterprises, researchers must also pay attention to the inherent particularity of Chinese families and Chinese society to better understand the behavior of private enterprises.

\section{Abbreviations}

CSR: Corporate social responsibility; SEW: Socioemotional wealth.

Acknowledgements

Not applicable.

Authors' contributions

Bin Zhu takes sole responsibility for this paper. The author read and approved the final manuscript.

Funding

Not applicable.

Availability of data and materials

Not applicable.

\section{Declarations}

Competing interests

The author declare no competing interests.

Received: 26 July 2021 Accepted: 3 November 2021

Published online: 24 November 2021 


\section{References}

Aguinis, Herman, and Ante Glavas. 2012. What We Know and Don't Know About Corporate Social Responsibility: A Review and Research Agenda. Journal of Management 38(4): 932-968.

Ashforth, Blake E., and Scott A. Johnson. 2001. Which Hat to Wear? The Relative Salience of Multiple Identities in Organizational Contexts. In Social Identity Processes in Organizational Contexts, ed. M.A. Hogg and D.J. Terly, 31-48. New York: Psychological Press.

Bassanini, Andrea, Eve Caroli, Antoine Rebérioux, and Thomas Breda. 2011. Working in Family Firms: Less Paid But More Secure? Evidence from French Matched Employer-Employee Data. Working Paper No. 5842. Institute for the Study of Labor (IZA), Boon, Germany.

Berle, Adolf A. 1931. Corporate Powers as Powers in Trust. Harvard Law Review 44(7): 1049-1074.

Berrone, Pascual, Cristina Cruz, and Luis R. Gomez-Mejia. 2012. Socioemotional Wealth in Family Firms Theoretical Dimensions, Assessment Approaches, and Agenda for Future Research. Family Business Review 25(3): 258-279.

Berrone, Pascual, Cristina Cruz, Luis R. Gomez-Mejia, and Martin Larraza-Kintana. 2010. Socioemotional Wealth and Corporate Responses to Institutional Pressures: Do Family-Controlled Firms Pollute Less? Administrative Science Quarterly 55(1): 82-113.

Block, Jörn. 2010. Family Management, Family Ownership, and Downsizing: Evidence from S\&P 500 firms. Family Business Review 23(2): 109-130.

Brammer, Stephen J., and Stephen Pavelin. 2006. Corporate Reputation and Social Performance: The Importance of Fit. Journal of Management Studies 43(3): 435-455.

Brammer, Stephen J., Stephen Pavelin, and Lynda A. Porter. 2009. Corporate Charitable Giving, Multinational Companies and Countries of Concern. Journal of Management Studies 46(4): 575-596.

Carroll, Archie B. 1991. The Pyramid of Corporate Social Responsibility: Toward the Moral Management of Organizational Stakeholders. Business Horizons 34(4): 39-48.

Cennamo, Carmelo, Pascual Berrone, Cristina Cruz, and Luis R. Gomez-Mejia. 2012. Socioemotional Wealth and Proactive Stakeholder Engagement: Why Family-Controlled Firms Care More About Their Stakeholders. Entrepreneurship Theory and Practice 36(6): 1153-1173.

Charkham, Jonathan P. 1992. Corporate Governance: Lessons from Abroad. European Business Journal 4(2): 8-16.

Chen, Honghui, and Shenghua Jia. 2004. Empirical Research on Stakeholders' 3-dimension Classification in Chinese Enterprises. Economic Research Journal 4: 80-90.

Chrisman, James J., Franz W. Kellermanns, Kam C. Chan, and Kartono L. Chrisman. 2010. Intellectual Foundations of Current Research in Family Business: An Identification and Review of 25 Influential Articles. Family Business Review 23(1): 9-26.

Christmann, Petra, and Glen Taylor. 2006. Firm Self-regulation Through International Certifiable Standards: Determinants of Symbolic Versus Substantive Implementation. Journal of International Business Studies 37(6): 863-878.

Chu, Xiaoping. 2000. Family Business Research: A Topic of Modern Significance. Social Sciences in China 5: 51-58.

Chu, Xiaoping. 2004. The Definition of Chinese Family Business. Economic Theory and Business Management 1: 49-53.

Clarkson, Max E. 1995. A Stakeholder Framework for Analyzing and Evaluating Corporate Social Performance. Academy of Management Review 20(1): 92-117.

Corbetta, Guido, and Carlo Salvato. 2004. Self-serving or Self-actualizing? Models of Man and Agency Costs in Different Types of Family Firms: A Commentary on 'Comparing the Agency Costs of Family and Nonfamily Firms: Conceptual Issues and Exploratory Evidence.' Entrepreneurship Theory and Practice 28(4): 355-362.

Davis, James H., F. David Schoorman, and Lex Donaldson. 1997. Toward a Stewardship Theory of Management. Academy of Management Review 22(1): 20-47.

Deephouse, David L., and Peter Jaskiewicz. 2013. Do Family Firms Have Better Reputations Than Nonfamily Firms? An Integration of Socioemotional Wealth and Social Identity Theories. Journal of Management Studies 50(3): 337-360.

Déniz, María de la Cruz Déniz., and Ma Katiuska Cabrera. Suarez. 2005. Corporate Social Responsibility and Family Business in Spain. Journal of Business Ethics 56(1): 27-41.

Donaldson, Thomas, and Thomas W. Dunfee. 1994. Toward a Unified Conception of Business Ethics: Integrative Social Contracts Theory. Academy of Management Review 19(2): 252-284.

Donaldson, Thomas, and Lee E. Preston. 1995. The Stakeholder Theory of the Corporation: Concepts, Evidence, and Implications. Academy of Management Review 20(1): 65-91.

Dutton, Jane E., Janet M. Dukerich, and Celia V. Harquail. 1994. Organizational Images and Member Identification. Administrative Science Quarterly 39(2): 239-263.

Dyer, W. Gibb., and David A. Whetten. 2006. Family Firms and Social Responsibility: Preliminary Evidence from the S\&P 500. Entrepreneurship Theory and Practice 30(6): 785-802.

Ebrey, Patricia. 1984. Conceptions of the Family in the Sung Dynasty. Journal of Asian Studies 43(2): 219-245.

Fama, Eugene F. 1980. Agency Problems and the Theory of the Firm. The Journal of Political Economy 88(2): 288-307.

Fei, Xiaotong. 1998. From the Soil: The Foundations of Chinese Society_Fertility System in Rural China. Beijing: Peking University Press.

Freeman, E. 2006. Strategic Management: A Stakeholder Approach, Wang Yanhua and Liang Hao Translated. Shanghai: Shanghai Translation Publishing House.

Freeman, R. Edward., and William M. Evan. 1990. Corporate Governance: A Stakeholder Interpretation. The Journal of Behavioral Economics 19(4): 337-359.

Freeman, E., J.S. Harrison, A.C. Wicks, B. Parmar, and S. Collet. 2013. Stakeholder Theory: The State of the Art, Sheng Ya and Li Jinghua Translated. Beijing: Intellectual Property Publishing House Co., Ltd.

Friedman, Milton. 1970. The Social Responsibility of Business is to Increase Its Profits. The New York Time Magazine (September 13):225-230

Fukuyama, F. 2001. Trust: The Social Virtues and the Creation of Prosperity Peng Zhihua Translated. Haikou: Hainan Press.

Gao, Yongqiang, Xiaobin He, and Lulu Li. 2011. Business Owners'Social Status, Economic Achievement and Corporate Philanthropy. Economic Research Journal 12: 111-123.

Godfrey, Paul C. 2005. The Relationship between Corporate Philanthropy and Shareholder Wealth: A Risk Management Perspective. Academy of Management Review 30(4): 777-798. 
Gómez-Mejía, Luis R., Cristina Cruz, Pascual Berrone, and Julio De Castro. 2011. The Bind that Ties: Socioemotional Wealth Preservation in Family Firms. The Academy of Management Annals 5(1): 653-707.

Gómez-Mejía, Luis R., Katalin Takacs Haynes, Manuel Nüñez-Nickel, Kathyrn J. L. Jacobson, and José Moyano-Fuentes. 2007. Socioemotional Wealth and Business Risks in Family-Controlled Firms: Evidence from Spanish Olive Oil Mills. Administrative Science Quarterly 52(1): 106-137.

Gómez-Mejía, Luis R., Marianna Makri, and Martin Larraza Kintana. 2010. Diversification Decisions in Family-Controlled Firms. Journal of Management Studies 47(2): 223-252.

Gómez-Mejía, Luis R., Manuel Nunez-Nickel, and Isabel Gutierrez. 2001. The Role of Family Ties in Agency Contracts. Academy of Management Journal 44(1): 81-95.

Granovetter, Mark. 1985. Economic Action and Social Structure: The Problem of Embeddedness. American Journal of Sociology 91(3): 481-510.

Hill, Charles, and Thomas Jones. 2010. Stakeholder-Agency Theory. Journal of Management Studies 29(2): 131-154.

Jensen, Michael C., and William H. Meckling. 1976. Theory of the Firm: Managerial Behavior, Agency Costs and Ownership Structure. Journal of Financial Economics 3(4): 305-360.

Jones, Thomas M. 1995. Instrumental Stakeholder Theory: A Synthesis of Ethics and Economics. Academy of Management Review 20(2): 404-437.

Kraus, Sascha, Rainer Harms, and Matthias Fink. 2011. Family Firm Research: Sketching a Research Field. International Journal of Entrepreneurship and Innovation Management 13(1): 32-47.

Le Breton-Miller, Isabelle, and Danny Miller. 2009. Agency Versus Stewardship in Public Family Firms: A Social Embeddedness Reconciliation. Entrepreneurship Theory and Practice 33(6): 1169-1191.

Le Breton-Miller, Isabelle, Danny Miller, and Richard H. Lester. 2011. Stewardship or Agency? A Social Embeddedness Reconciliation of Conduct and Performance in Public Family Businesses. Organization Science 22(3): 704-721.

Li, Xinchun. 2002. Trust, Loyalty and the Predicament that Clannishness. Management World 6: 87-93.

$\mathrm{Li}$, Xinchun. 2003. The Dysfunction of Markets of Managing Agents, and the Control of Clannish Enterprises. Management World 4: 87-95.

Li, Sihai. 2010. Institutional Environments, Political Relationship and Corporate Donation. China Accounting Review 2: 161-178.

Li, Haiqin, and Zigang Zhang. 2010. An Empirical Study on the Effects of Corporate Social Responsibility on Corporate Reputation and Customer Loyalty. Nankai Business Review 1: 90-98.

Li, Lulu, and Bin Zhu. 2014. Family Involvement, Firm Size and the Performance of Private Enterprises. Sociological Studies 2: $1-21$.

Liang, Jian, Shuangying Chen, and Qingen Gai. 2010. Political Participation, Governance Structure and Charitable Donation of Private Enterprises. Management World 7: 109-118.

Maignan, Isabelle, Odies Collins Ferrell, G. Tomas, and M. Hult. 1999. Corporate Citizenship: Cultural Antecedents and Business Benefits. Journal of the Academy of Marketing Science 27(4): 455-469.

MitChell, Ronald K., Bradley R. Agle, and Donna J. Wood. 1997. Toward a Theory of Stakeholder Identification and Salience: Defining the Principle of Who and What Really Counts. Academy of Management Review 22(4): 853-886.

Morck, Randall, and Bernard Yeung. 2003. Agency Problems in Large Family Business Groups. Entrepreneurship Theory and Practice 27(4): 367-382.

Morck, Randall, and Bernard Yeung. 2004. Family Control and the Rent-Seeking Society. Entrepreneurship Theory and Practice 28(4): 391-409.

Mudrack, Peter. 2007. Individual Personality Factors that Affect Normative Beliefs About the Rightness of Corporate Social Responsibility. Business and Society 46(1): 33-62.

Muller, Alan, and Ans Kolk. 2010. Extrinsic and Intrinsic Drivers of Corporate Social Performance: Evidence from Foreign and Domestic Firms in Mexico. Journal of Management Studies 47(1): 1-26.

Reid, Renee S., and Richard Harris. 2002. The Determinants of Training in SMEs in Northern Ireland. Education and Training 44(8/9): 443-450.

Sen, Sankar, and Chitra Bhanu Bhattacharya. 2001. Does Doing Good Always Lead to Doing Better? Consumer Reactions to Corporate Social Responsibility. Journal of Marketing Research 38(2): 225-243.

Stavrou, Eleni, George Kassinis, and Alexis Filotheou. 2007. Downsizing and Stakeholder Orientation Among the Fortune 500: Does Family Ownership Matter? Journal of Business Ethics 72(2): 149-162.

Uhlaner, Lorraine M., H.J.M. van Goor-Balk, and Enno Masurel. 2004. Family Business and Corporate Social Responsibility in a Sample of Dutch Firms. Journal of Small Business and Enterprise Development 11(2): 186-194.

Zellweger, Thomas M., Robert S. Nason, Mattias Nordqvist, and Candida G. Brush. 2013. Why Do Family Firms Strive for Nonfinancial Goals? An Organizational Identity Perspective. Entrepreneurship Theory and Practice 37(2): 229-248.

Zheng, Boxun. 2005. Difference Order Pattern and Chinese Organization and Behavior. In Family Business: Organization, Action and Chinese Economy, ed. Li. Xinchun and Zhang Shujun, 297-378. Shanghai: SDX Joint Publishing Company.

Zhou, Lixin. 2011. Family Involvement and Corporate Social Responsibility: Manufacturing Evidence from China. Business Management Journal 9: 45-53.

Zhou, Zhongsheng, Dexu He, and Zheng Li. 2012. Institutional Environment and Corporate Social Responsibility: Evidence from Listed Companies in China. China Soft Science 10: 59-68.

Zhou, Hualin, and Xuesong Li. 2012. Estimation Method and Application of Tobit Model. Economic Perspectives 5: 105-119.

\section{Publisher's Note}

Springer Nature remains neutral with regard to jurisdictional claims in published maps and institutional affiliations. 